\title{
Eykur notkun kannabis hættu á geðrofi og próun geðklofa?
}

Arnar Jan Jónsson¹ læknanemi, Hera Birgisdóttir læknanemi, Engilbert Sigurðsson¹,2 læknir

\section{ÁGRIP}

Á síðustu 30 árum hefur vísbendingum fjölgað um að kannabisreykingar auki hættu á geðrofi (psychosis) sem geti próast áfram í geðklofa hjá hluta slíkra einstaklinga. Síðasta áratug hafa verið birtar margar rannsóknir sem skýra tengsl kannabis og geðrofs. Markmið pessarar yfirlitsgreinar er að taka saman og fjalla um pessi tengsl. Farið er yfir niðurstöður 14 ferilrannsókna á 9 rannsóknarpýðum og 9 tilfellaviðmiðarannsókna. Pegar niðurstöður peirra eru teknar saman styðja pær ótvírætt að notkun kannabis sé sjálfstæður áhættupáttur fyrir geðrof og að öllum líkindum einnig fyrir próun langvinnra geðrofssjúkdóma eins og geðklofa. Um skammtaháð samband er að ræða par sem áhættan eykst með tíðari neyslu. Einnig sýna rannsóknir að notkun kannabis á unglingsaldri hefur sterkari tengs। við geðrof en neysla sem hefst á fullorðinsárum. Frekari rannsókna er pó pörf enda geta geðrofssjúkdómar verið lengi í próun og vandasamt að mæla skýribreytu og svarbreytu og flókið samband peirra. Við teljum mikilvægt að auka pekkingu almennings á alvarlegum afleiðingum kannabisnotkunar og peirri staðreynd að ekki er hægt að spá fyrir um hverjir peirra sem nota efnið reglulega veikist af skammvinnu geðrofi og hverjir af langvinnum geđrofssjúkdómi.
Engilbert Sigurðsson engillbs@landspitali.is

\section{Inngangur}

Kannabis er samheiti yfir virk efni sem finna má í plöntunni Cannabis sativa. Frá alda öðli hafa menn notað plöntuna til að breyta líðan eða komast í vímu. Í dag er kannabis einn mest notaði vímugjafi í heiminum. Alpjóðaheilbrigðisstofnunin áætlar að árlega noti 147 milljónir manna kannabis, eða rúmlega 2\% jarðarbúa. ${ }^{1}$ Í skýrslu Rannsókna og greiningar árið 2012 kemur fram að tíðni notkunar á kannabis einu sinni eða oftar um ævina hjá unglingum í 10. bekk á Íslandi var 9\% árið 2009 og 7\% árið 2012. ${ }^{2}$ Ætla verður að um nokkuð áreiðanlegar tölur sé að ræða par sem hlutfall grunnskólanema sem hafa tekið pátt í könnuninni hefur verið afar hátt og nam til dæmis 86\% árið 2012. ${ }^{2}$

Talið er að tetrahydrocannabinol (THC) og skyld virk efni í kannabis verki á viðtaka (CB1 og CB2) sem finna má víða í líkamanum en enn er pó ekki vitað hvaða hlutverki peir gegna í mönnum. ${ }^{3}$ Prátt fyrir útbreidda notkun kannabisefna í mörgum löndum á síðustu áratugum er enn margt óljóst um áhrif efna sem bindast pessum viðtökum í líkamanum. Par er bæði um að ræða endogen (efni mynduð í líkamanum) og exogen eða utanaðkomandi kannabinoid-efni. Mest er vitað um virkni exogen efnisins delta-9-tetrahydrocannabinols (oftast vísað til pess sem THC).

Um áratugaskeið hafa vísbendingar verið um að kannabis auki hættu á geðsjúkdómum, einkum geðrofi (psychosis), sem gæti með tímanum próast í geðklofa hjá hluta slíkra einstaklinga. Árið 1987 birtist loks umfangsmikil ferilrannsókn, gerð á hermönnum í Svípjóð, sem kannaði pessi tengsl. Í rannsókninni var aðferðum faraldsfræðinnar beitt til að kanna tengsl kannabisnotkunar og próunar geðklofa í kjölfarið í fjölmennu pýði. ${ }^{4}$ Niðurstöðurnar mörkuðu viss tímamót í pekk- ingarleit á pessu sviði. Rannsóknin sýndi að endurtekin neysla kannabisefna eykur hættu á geðrofi og í kjölfarið hættu á alvarlegum geðrofssjúkdómi eins og geðklofa hjá ungum karlmönnum. Síðan hafa birst margar rannsóknir sem styrkja meginniðurstöður sænsku hermannarannsóknarinnar og verða pær kynntar í pessari yfirlitsgrein. Einnig hafa verið birtar fjölmargar rannsóknir sem styðja að notkun kannabisefna geti valdið versnun á geðrofssjúkdómi hjá peim sem hafa greinst með slíka sjúkdóma, svo sem geðklofa. Pó hafa verið deilur um hvort tengslin felist frekar í pví að kannabis valdi geðrofi eða hvort fylgnin kunni að skýrast af pví að peir sem fara í geðrofsástand séu líklegri til að nota efnið en aðrir og notkunin auki í raun ekki hættuna á geðrofi. Ferilrannsóknir eru öflugasta rannsóknarsniðið til að varpa ljósi á pessi tengsl. Í pessari grein eru teknar saman og fjallað um helstu niðurstöður rannsókna sem birst hafa um tengsl kannabisnotkunar, geðrofs og geðklofa.

\section{Aðferðir}

Gerð var gagnaleit pann 15.01.2013 og aftur 01.10.2013 í gagnasafninu PubMed með leitarskilyrðunum „Schizophrenia and Disorders with Psychotic Features AND Cannabis" og "Schizophrenia and Disorders with Psychotic Features AND Marijuana abuse“. Pegar búið var að taka út greinar sem komu fram tvisvar stóð eftir 801 grein frá árunum 1962-2013. Valdar voru greinar með ensku ágripi og á ensku sem fjölluðu um notkun kannabis og afleiðingar hennar meðal manna. Alls voru 408 ágrip lesin og 111 greinar valdar til frekari yfirferðar. Við val greina var meðal annars tekið tillit til fjölda til- 


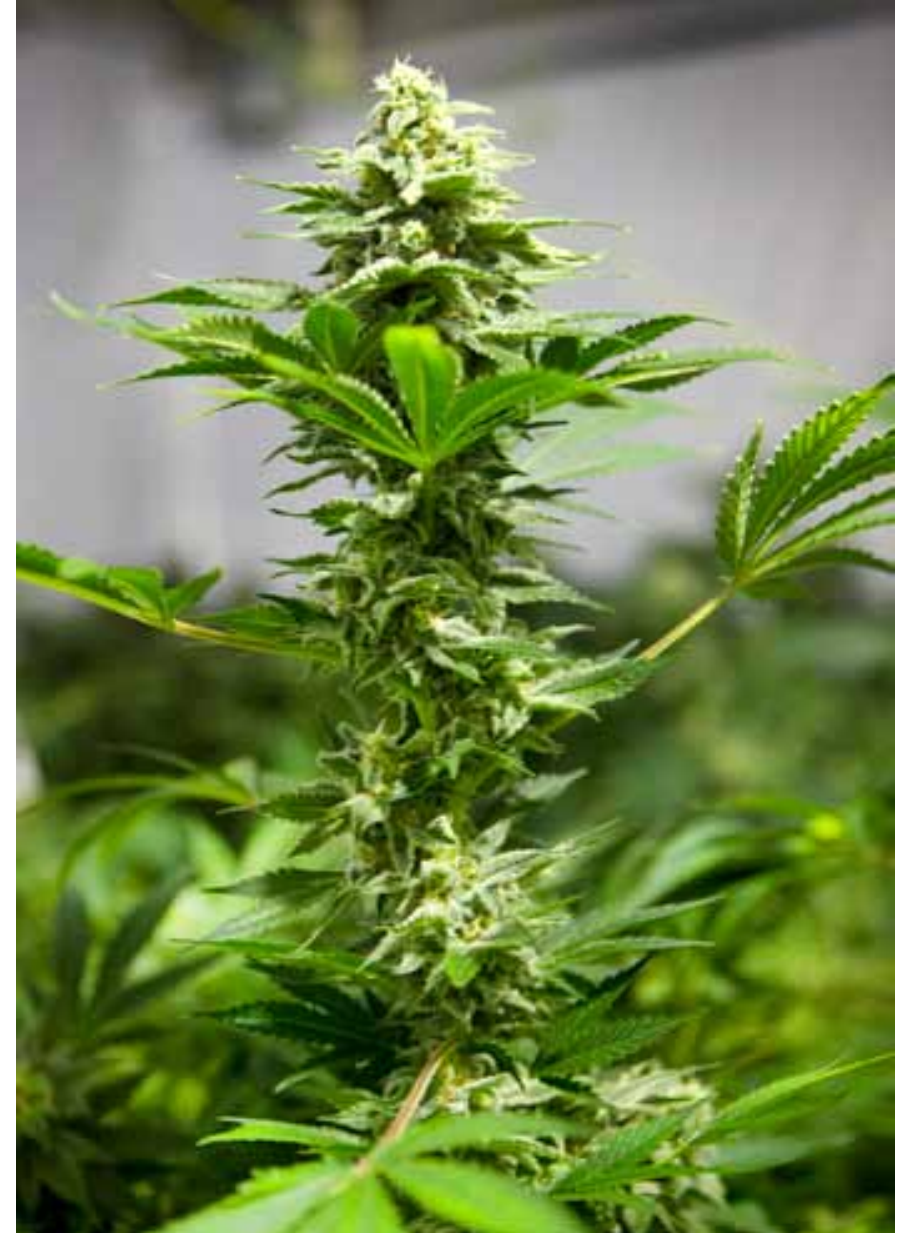

Mynd 1. Cannabis sativa. Mynd Júlíus Sigurjónsson.

vitnana í greinina, hvort aðalumfjöllunarefni greinar væri tengsl kannabis og geðrofs eða tengsl kannabis og geðsjúkdóma. Meðal greina sem ákveðið var að fjalla ekki um voru greinar par sem aðallega voru metin tengsl annarra vímuefna við geðsjúkdóma pótt kannabis væri einnig nefnt í pví samhengi. Sérstaklega voru valdar lýðgrundaðar ferilrannsóknir og tilfellaviðmiðarannsóknir en sjúkratilfellum og tilfellaröðum sleppt. Einnig var valið að fjalla ekki um fjölmargar rannsóknir sem fjölluðu um hugsanlega samverkan kannabis og erfða, en mikil óvissa er um margt í pví samspili og sú umfjöllun í raun efni í aðra grein.

\section{Yfirlit ferilrannsókna}

Niðurstöður lýsandi faraldsfræðirannsókna benda til pess að endurtekin notkun kannabis sé marktækt algengari hjá peim sem veikjast af geðrofi með ofskynjunum og ranghugmyndum. ${ }^{5-7}$ I niðurstöðum leitar voru 14 ferilrannsóknir, gerðar á 9 rannsóknarpýðum. Meginniðurstöður peirra verða nú raktar.

\section{Sænska ferilrannsóknin}

Rannsókn Andreasson og samverkamanna var fyrsta ferilrannsóknin sem studdi að notkun kannabis væri sjálfstæður áhættupáttur fyrir geðrofi. ${ }^{4}$ Rannsóknin birtist árið 1987 og samanstóð rannsóknarbýðið af 45.570 Svíum sem gengu í sænska herinn á árunum 1969-1970. Við innritun í herinn við 18 ára aldur var safnað upplýsingum um notkun kannabis og annarra vímuefna ásamt upplýsingum um ýmsa félagslega og geðræna pætti hjá 93\% pátttakenda. Niðurstöður sýndu skammtaháð samband notkunar kannabis við 18-20 ára aldur og innlagnar á spítala vegna geðrofs einhvern tíma á næstu 15 árum. Peir sem höfðu notað kannabis 1050 sinnum voru prefalt líklegri til að hafa lagst inn á spítala vegna geðrofs heldur en peir sem aldrei höfðu notað kannabis. Nær einn af hverjum 10 hafði notað kannabis og 1,7\% voru skilgreindir sem stórnotendur par sem peir höfðu notað pað oftar en 50 sinnum. ${ }^{4}$ Pegar leiðrétt var fyrir páttum sem gátu truflað vensl kannabis og geðklofa, svo sem geðrænum einkennum við inngöngu í herinn, lækkaði petta hlutfall úr 3,0 í 2,9 en hélst marktækt (tafla I). Frekari leiðrétting fyrir páttum eins og tilvist annarra geðraskana, fjölskyldusögu og notkun annarra fíkniefna lækkaði petta líkindahlutfall í 2,3 og var pað pá ekki lengur tölfræðilega marktækt. Peir sem höfðu notað kannabis 50 sinnum eða oftar voru hins vegar 6 sinnum líklegri en hinir sem ekki höfðu notað kannabis til að hafa lagst inn á geðdeild í geðrofi. Leiðrétt líkindahlutfall var hins vegar ekki birt fyrir pann undirhóp og hefur rannsóknin verið gagnrýnd fyrir pað. Einnig hefur verið bent á að nokkrir pekktir áhættupættir og mögulegir truflandi pættir voru ekki nægilega vel skilgreindir. Par ber að nefna pætti eins og örvandi vímuefni á borð við amfetamín, persónuleikapætti tengda fíkn og félagslega stöðu. Einnig að aðeins var tekið tillit til geðgreininga við innritun en einkenni geðrofs pá ekki metin sérstaklega.

Ári síðar var gerð frekari rannsókn á úrtaki hópsins, einstaklingum sem bjuggu í Stokkhólmi. ${ }^{8}$ Einstaklingar sem höfðu notað kannabis 10 sinnum eða oftar og síðar greinst með geðklofa voru bornir saman við samanburðarhóp úr pýðinu sem aldrei hafði notað kannabis. Farið var yfir sjúkrasögu pátttakenda og ýmsum páttum voru gerð betri skil, svo sem notkun kannabis og annarra vímuefna, upphafi geðsjúkdóms, fjölskyldusögu um geðsjúkdóma og félagslegri stöðu, til að hægt væri að leiðrétta fyrir peim ef ástæða væri til. Niðurstöðurnar staðfestu fyrri niðurstöður: peir sem höfðu notað kannabis 50 sinnum eða oftar voru marktækt líklegri til að hafa í kjölfarið greinst með geðklofa, OR 4,1 (95\%CI: 1,8-9,3) (tafla I).

Endurgreining á pýðinu var birt árið 2002. Pegar gögnunum var pá safnað voru liðin 27 ár frá innritun hermannanna í sænska herinn. Niðurstöður pessarar nánari úrvinnslu voru að notkun kannabis væri sjálfstæður áhættupáttur fyrir geðklofa og reyndist áhættan standa í beinu línulegu sambandi við tíðni notkunar á kannabisefnum (línulegt samband 1,3 (95\%CI 1,1-1,6) fyrir hvern 5 flokka notenda). ${ }^{9}$ Leiðrétt líkindahlutfall peirra sem einhvern tíma höfðu notað kannabis var 1,5 (95\%CI 1,1-2,0) og fyrir pá sem höfðu notað pað 50 sinnum eða oftar reyndist pað 3,1 (95\%CI 1,75,5). Í pessari framhaldsrannsókn á sænska hermannapýðinu voru undirliggjandi áhættu- og truflandi páttum á borð við félagslega pætti, geðræn einkenni, greind og vímuefnum gerð betri skil en í fyrri rannsóknum á pýðinu.

Nýlega voru birt gögn eftir 35 ára eftirfylgd. Pau staðfestu fyrri niðurstöður og reyndist leiðrétt líkindahlutfall par 3,7 (95\%CI: 2,3$5,8)$ fyrir að greinast með geðklofa í kjölfar reglulegrar kannabisnotkunar einstaklinga í ofangreindu pýði. ${ }^{10}$

\section{Epidemiologic Catchment Area-rannsóknin}

Á árunum 1980-1984 var skipulögð umfangsmikil rannsókn, Epidemiologic Catchment Area-rannsóknin (ECA), með pað аð 
Tafla I. Ferilrannsóknir sem greinarhöfundar vísa til um tengsl kannabis og geđrofs.

\begin{tabular}{|c|c|c|c|c|c|c|c|c|}
\hline Höfundar & Ár & Ferilhópur & Aldur & Fjöldi & $\begin{array}{c}\text { Mæling } \\
\text { svarbreytu* }^{*}\end{array}$ & Svarbreyta & Truflandi pættir & $\mathrm{OR}^{\star \star}(95 \% \mathrm{Cl})$ \\
\hline $\begin{array}{l}\text { Andreasson } \\
\text { et } \mathrm{al}^{4}\end{array}$ & 1987 & Sænskir hermenn & 18-20 ár & 50.465 & $\begin{array}{c}\text { Innlagnir } \\
\text { vegna geðrofs }\end{array}$ & Geðklofi & Geðræn einkenni við innritun í herinn & $2,9(1,9-4,4)$ \\
\hline $\begin{array}{l}\text { Andreasson } \\
\text { et } \mathrm{al}^{8}\end{array}$ & 1989 & Sænskir hermenn & 18-20 ár & 7695 & $\begin{array}{l}\text { Greining } \\
\text { geðklofa }\end{array}$ & Geðklofi & $\begin{array}{l}\text { Líkindahlutfall, ekki leiðrétt fyrir } \\
\text { hugsanlegum truflandi páttum }\end{array}$ & $4,1(1,8-9,3)$ \\
\hline $\begin{array}{l}\text { Tien \& } \\
\text { Antony }^{12}\end{array}$ & 1990 & $\begin{array}{l}\text { Epidemiologic } \\
\text { Catchment Area } \\
\text { (ECA) }\end{array}$ & 18-49 ár & 4994 & DIS & Einkenni geðrofs & $\begin{array}{l}\text { Kyn, skólasókn, menntunarstig, } \\
\text { hjúskaparstaða, atvinnustaða, } \\
\text { punglyndi, örlyndi, víðáttufælni, } \\
\text { áráttupráhyggjuröskun }\end{array}$ & $2,0(1,3-3,1)$ \\
\hline Zammit et al ${ }^{9}$ & 2002 & Sænskir hermenn & 18-20 ár & 50.087 & $\begin{array}{l}\text { Innlagnir vegna } \\
\text { geðrofs }\end{array}$ & $\begin{array}{l}\text { Innlagnir vegna } \\
\text { geðrofs }\end{array}$ & $\begin{array}{l}\text { Greindarvísitala, óeðlileg hegðun, } \\
\text { reykingar, utangarðsbúseta }\end{array}$ & $3,1(1,7-5,5)$ \\
\hline Van Os et $\mathrm{al}^{13}$ & 2002 & NEMESIS & 18-64 ár & 4045 & $\begin{array}{l}\text { CIDI, SCID og } \\
\text { klínísk viðtöl }\end{array}$ & $\begin{array}{l}\text { Einkenni geðrofs } \\
\text { eða greining } \\
\text { geðrofssjúkdóms }\end{array}$ & $\begin{array}{l}\text { Aldur, kynpáttur, menntun, búseta, } \\
\text { hjúskaparstaða og mismunun }\end{array}$ & $16,9(3,3-86,1)$ \\
\hline $\begin{array}{l}\text { Arseneault } \\
\text { et } \mathrm{al}^{14}\end{array}$ & 2002 & Dunedin & 26 ár & 759 & $\begin{array}{l}\text { Greiningarviðtöl, } \\
\text { DSM-IV }\end{array}$ & $\begin{array}{c}\text { Einkenni geðklofa og } \\
\text { punglyndis. Greining } \\
\text { schizophreniform } \\
\text { disorder og } \\
\text { punglyndi. }\end{array}$ & $\begin{array}{l}\text { Félagsleg staða, kyn, einkenni } \\
\text { geðrofs við } 11 \text { ára aldur }\end{array}$ & $3,1(0,7-13,3)$ \\
\hline Phillips et al ${ }^{16}$ & 2002 & $\begin{array}{l}\text { Hááhættuhópur } \\
\text { m.t.t. ættarsögu }\end{array}$ & 14-28 ár & 100 & $\begin{array}{l}\text { PACE skilmerki } \\
\text { bráðs geðrofs }\end{array}$ & Geðrof & Ekki nefndir & Ekki birt \\
\hline $\begin{array}{l}\text { Fergusson } \\
\text { et } \mathrm{al}^{17}\end{array}$ & 2003 & CHDS & $\begin{array}{l}18 \text { og } \\
21 \text { ár }\end{array}$ & 1053 & $\begin{array}{l}\text { Sjálfsmat (SCL- } \\
\text { 90) }\end{array}$ & Einkenni geðrofs & $\begin{array}{l}\text { Fyrri geðrofseinkenni, önnur vímuefni, } \\
\text { einkenni annarra geðsjúkdóma samkvæmt } \\
\text { CIDI, félagslegar aðstæður } \\
\text { og fjölskylduaðstæður }\end{array}$ & $1,8(1,2-2,6)$ \\
\hline $\begin{array}{l}\text { Fergusson } \\
\text { et } \mathrm{al}^{18}\end{array}$ & 2005 & CHDS & 25 ár & 1055 & $\begin{array}{l}\text { Greiningarviðtöl, } \\
\text { DSM-IV }\end{array}$ & $\begin{array}{l}\text { Einkenni geðklofa og } \\
\text { punglyndis. Greining } \\
\text { schizophreniform } \\
\text { disorder og } \\
\text { punglyndi. }\end{array}$ & $\begin{array}{c}\text { Kyn, menntun foreldra, félagsleg staða, } \\
\text { neysla foreldra, geðsjúkdómar foreldra, } \\
\text { áföll í ææsku, fyrri geðsaga, neysla annarra } \\
\text { vímuefna en kannabis }\end{array}$ & $1,6(1,2-2,0)$ \\
\hline $\begin{array}{l}\text { Henquet et } \\
\mathrm{al}^{19}\end{array}$ & 2005 & $\begin{array}{l}\text { Early } \\
\text { developmental } \\
\text { stages of } \\
\text { pathology (EDSP) }\end{array}$ & 14-24 ár & 2437 & $\mathrm{M}-\mathrm{CIDI}$ & $\begin{array}{l}1-2 \text { atriði af } \\
15 \text { á M-CIDI } \\
\text { spurningalista með } \\
\text { tilliti til geðrofs. }\end{array}$ & $\begin{array}{c}\text { Aldur, kyn, félagsleg staða, búseta í borg, } \\
\text { áföll i æsku, einkenni geðrofs við upphaf } \\
\text { rannsóknar, reykingar, neysla alkóhóls og } \\
\text { annarra vímuefna en kannabis }\end{array}$ & $1,7(1,1-2,5)$ \\
\hline Wiles et $a^{22}$ & 2006 & $\begin{array}{c}\text { National } \\
\text { Psychiatric } \\
\text { Morbidity Survey }\end{array}$ & 16-74 ár & 1795 & $\begin{array}{c}\text { Psychosis } \\
\text { Screening } \\
\text { Questionnaire } \\
\text { (PSQ) }\end{array}$ & $\begin{array}{l}\text { Geðrofseinkenni og/ } \\
\text { eða oflæti }\end{array}$ & $\begin{array}{l}\text { Aldur, kyn, hjúskaparstaða, } \\
\text { greindarvísitala, búseta, meiriháttar } \\
\text { atburðir í lífi, reykingar, menntun, vinna, } \\
\text { félagsleg staða, tekjur }\end{array}$ & $1,5(0,6-3,9)$ \\
\hline $\begin{array}{l}\text { McGrath et } \\
\mathrm{al}^{24}\end{array}$ & 2010 & $\begin{array}{l}\text { Mater-University } \\
\text { Study of } \\
\text { Pregnancy }\end{array}$ & 18-23 ár & 3801 & $\begin{array}{l}\text { Ekki-affectíf } \\
\text { geðrofsgreining, } \\
\text { ofskynjanir, } \\
\text { CIDI og PDI }\end{array}$ & $\begin{array}{l}\text { Ekki-affectíf } \\
\text { geðrofsgreining, } \\
\text { einkenni geðrofs }\end{array}$ & $\begin{array}{l}\text { Kyn, aldur, ofskynjanir við } 14 \text { ára aldur, } \\
\text { geđsjúkdómar foreldra }\end{array}$ & $2,1(1,002-4,3)$ \\
\hline $\begin{array}{l}\text { Kuepper et } \\
\mathrm{al}^{20}\end{array}$ & 2011 & $\begin{array}{l}\text { Early } \\
\text { developmental } \\
\text { stages of } \\
\text { pathology (EDSP) }\end{array}$ & 14-24 ár & 1923 & $\mathrm{M}-\mathrm{CIDI}$ & Einkenni geðrofs & $\begin{array}{l}\text { Aldur, kyn, félagsleg staða, neysla annarra } \\
\text { vímugjafa, áföll í ææsku, ekki föst búseta. } \\
\text { Neysla kannabisefna og geðrofseinkenni } \\
\text { ekki til staðar við upphaf rannsóknar }\end{array}$ & $1,9(1,1-3,1)$ \\
\hline $\begin{array}{l}\text { Manrique- } \\
\text { Garcia et } \mathrm{al}^{10}\end{array}$ & 2012 & Sænskir hermenn & 18-20 ár & 41.943 & $\begin{array}{l}\text { Innlagnir vegna } \\
\text { geðrofs }\end{array}$ & $\begin{array}{c}\text { Innlagnir } \\
\text { vegna geđrofs, } \\
\text { geðrofssjúkdómar }\end{array}$ & $\begin{array}{l}\text { Geðgreiningar við upphaf rannsóknar, } \\
\text { greindarvísitala, andfélagsleg hegðun, } \\
\text { búseta í borg, tóbaksreykingar }\end{array}$ & $3,7(2,3-5,8)$ \\
\hline
\end{tabular}

${ }^{*} \mathrm{DIS}=$ Diagnostic Interview Schedule, SCID=Structured Clinical Interview for DSM-III-R / IV, PACE= Personal Assessment and Crisis Evaluation, SCL-90= Symptom Checklist 90, PDI= Peter's et al Delusional Inventory, $\mathrm{CIDI}=$ Composite International Diagnostic Interview, M-CIDI= Munich Composite International Diagnostic Interview.

**Líkindahlutfall, OR, leiðrétt fyrir truflandi páttum nema annað sé tekið fram.

markmiði að auka pekkingu á faraldsfræði geðsjúkdóma í Bandaríkjunum. ${ }^{11}$ Valið var slembiúrtak í fimm borgum til að svara fjölmörgum spurningum, par á meðal varðandi notkun vímuefna og um geðrofseinkenni. Tekin voru tvö viðtöl með árs millibili. Tien og Anthony birtu niðurstöður sínar um tengsl kannabisnotkunar og geðrofs í ECA-rannsókninni árið 1990.12 (tafla I) Pegar búið var að leiðrétta fyrir truflandi páttum á borð við skólasókn, menntunarstig, hjúskaparstöðu, atvinnustöðu og geðræn einkenni við upphaf rannsóknar, voru peir sem notuðu kannabis daglega í tvöfalt meiri áhættu á að hafa fengið geðrofseinkenni en peir sem ekki höfðu notað kannabis (95\%CI: 1,3-3,1).

\section{Nemesis-rannsóknin}

Árið 2002 birtist lýðgrunduð rannsókn byggð á hollensku úrtaki einstaklinga á aldrinum 18-64 ára en gögnunum hafði verið safnað á árunum 1996-1999.13 Rannsóknin studdi að notkun kannabis við upphaf rannsóknar margfaldaði líkurnar á geðrofi prem 
árum seinna (OR: 24,2 ; 95\%CI: 5,4-107,5). Leiðrétt var fyrir aldri, kynpætti, menntun, búsetu, hjúskaparstöðu og mismunun (tafla I). Petta var miklu hærra líkindahlutfall en aðrir rannsakendur höfðu birt á peim tíma. Áhættan var skammtaháð líkt og í fyrri rannsóknum og jókst marktækt með aukinni notkun. Pegar áhrif kannabis á geðrof voru leiðrétt fyrir áhrifum notkunar annarra vímuefna lækkaði líkindahlutfallið fyrir notkun kannabis lítið eitt en hélst samt mjög marktækt; OR 16,9 (95\% CI: 3,3-86,1). Einn af styrkleikum pessarar rannsóknar er að peir sem höfðu einkenni geðrofs við upphaf rannsóknartímans voru ekki teknir með í tölfræðilegum útreikningum á líkindahlutfallinu. Höfundar álykta að með pví móti væri vissan meiri um að aukin hætta á geðrofi hjá kannabisnotendum væri í raun afleiðing peirrar notkunar. Að auki gátu peir sýnt fram á að áhrif örvandi efna á geðrof voru afar lítil og ómarktæk ein og sér, en sumar fyrri rannsóknir höfðu verið gagnrýndar fyrir að leiðrétta ekki fyrir hugsanlegum samhliða áhrifum notkunar örvandi efna eins og amfetamíns.

\section{Dunedin-rannsóknin}

Dunedin-ferilhópurinn samanstendur af 1037 einstaklingum fæddum í Dunedin á Nýja-Sjálandi frá 1. apríl 1972 til 31. mars 1973. Hópnum hefur verið fylgt eftir allt frá fæðingu og er öllum í hópnum boðið reglulega til mats á páttum tengdum heilsufari, ýmsum venjum og fleiri páttum.

Árið 2002 birtu Arseneault og samverkamenn rannsókn par sem gögn sem safnað hafði verið til 26 ára aldurs lágu fyrir. ${ }^{14}$ Notkun kannabis var fyrst metin við 15 ár og aftur við 18 ára aldur. Geðrofseinkenni voru hins vegar metin við 11 ára aldur og á ný við 26 ára aldur. Niðurstöðurnar Dunedin-ferilrannsóknarinnar voru að kannabisnotkun við 15 ára aldur jók marktækt líkur á geðrofseinkennum fyrir 26 ára aldur. Pegar leiðrétt var fyrir geðrofseinkennum við 11 ára aldur minnkaði pessi áhætta og var ekki lengur marktæk pótt líkindahlutfallið væri allhátt, OR 3,1 (95\%CI 0,7-13,3) (tafla I). Kannabisnotkun við 18 ára aldur jók ekki marktækt líkur á geðrofseinkennum fyrir 26 ára aldur.

\section{PACE-rannsóknin}

The Personal Assessment and Crisis Evaluation (PACE) heilbrigðisstofnunin er sérhæfð stofnun í Melbourne í Ástralíu, sem sérhæfir sig í rannsóknum og meðferð á ungu fólki sem er talið vera í aukinni hættu á að fá geðrofssjúkdóm, til að mynda vegna ættarsögu. ${ }^{15}$ Til að flokkast í hárri áhættu á geðrofi og mega piggja pjónustu stofnunarinnar verða einstaklingarnir að uppfylla ákveðin skilyrði. Meðal peirra er að hafa ekki farið í geðrof og ekki heldur verið á geðrofslyfjum. Aldur einstaklinga í pýðinu var frá 14 til 30 ára á rannsóknartímanum.

Rannsókn byggð á sambandi kannabisnotkunar og geðrofs í pessu pýði var birt árið 2002. Rannsakendur fylgdu síðan 100 einstaklingum úr hópnum eftir í eitt ár. ${ }^{16}$ Í upphafi var notast við skilgreinda kvarða til að meta félagslega hæfni, geðrofseinkenni og fleira. Kannabisnotkun var metin af pátttakendum og var notast við DSM-IV skilgreiningu á kannabisfíkn. Eftir 12 mánaða eftirfylgd höfðu 39\% peirra sem háðir voru kannabisefnum próað með sér geðrof samanborið við 31\% peirra sem ekki voru háðir efninu en munurinn mældist ekki marktækur (líkindahlutfall ekki birt í grein) (tafla I). Hópnum var einnig skipt upp eftir tíðni kannabisnotkunar. Aftur fannst ekki marktækur munur á algengi geðrofs milli peirra sem notuðu kannabis einu sinni eða oftar í viku samanborið við pá sem notuðu pað einu sinni eða sjaldnar en einu sinni í viku (37\% á móti 39\%, í sömu röð).

\section{Christchurch Health and Developmental-rannsóknin}

Christchurch Health and Developmental ferilhópurinn (CHDS) samanstendur af 1265 einstaklingum fæddum í Christchurch á NýjaSjálandi árið 1977. Hópnum hefur verið fylgt eftir frá fæðingu og einstaklingum í honum er reglulega boðið að koma til mats á páttum tengdum heilsufari, venjum og öðru. Meðal annars er spurt um kannabisnotkun, einkenni geðrofs og önnur einkenni geðsjúkdóma.

Árið 2003 birtu Fergusson og samverkamenn grein um tengsl kannabisnotkunar og geðrofseinkenna. ${ }^{17}$ Notuð voru gögn úr CHDS sem aflað var við 18 ára og 21 árs aldur. Staðlaðir spurningalistar voru notaðir til mats og var tímasetningu kannabisnotkunar og geðrofseinkenna gerð góð skil. Niðurstöður voru að einstaklingar sem notuðu kannabis voru marktækt líklegri til að hafa fengið geðrofseinkenni. Leiðrétt líkindahlutfall reyndist 1,8 (95\%CI 1,2-2,6) (tafla I).

Árið 2005 birtu Fergusson og samverkamenn grein par sem tengslin á milli notkunar kannabis og geðrofs voru rannsökuð frekar í sama ferilhópi. ${ }^{18}$ Í petta sinn voru gögn notuð frá mati sem gert var pegar einstaklingarnir voru 18 ára, 21 árs og 25 ára gamlir. Niðurstöður sýndu að nýgengishlutfall geðrofseinkenna (incidence rate ratio, IRR) peirra sem notuðu kannabis daglega var um $60 \%$ hærra en hjá viðmiðunarhópnum (IRR 1,6; 95\%CI 1,2-2,0). Sýnt var fram á marktæk tengsl milli mikillar notkunar kannabis og geðrofs í kjölfarið. Höfundar ályktuðu að orsakatengsl væru á milli notkunar kannabis og próunar geðrofseinkenna sem ekki væri hægt að skýra með hliðsjón af hugsanlegum truflandi páttum á borð við ýmsa félagslega pætti, fyrri sögu um geðsjúkdóma eða með hliðsjón af notkun annarra vímuefna.

\section{Early developmental stages of pathology-rannsóknin (EDSP)}

Pýskur rannsóknarhópur í München hóf framskyggna ferilrannsókn árið 1994 til að meta faraldsfræði og próun geðsjúkdóma. Slembiúrtaki 3021 manna hóps á aldrinum 14 til 24 ára var fylgt eftir í 10 ár par sem einstaklingarnir svöruðu spurningalistum (Munich Composite International Diagnostic Interview) með nokkurra ára millibili. Lögð var áhersla á að meta algengi geðsjúkdóma, einkenni peirra og fylgisjúkdóma (comorbidity). Tvær ferilrannsóknir um tengsl kannabisnotkunar og einkenni geðrofs í EDSP hafa verið birtar. Henquet og samverkamenn birtu pá fyrri árið 2005 og byggðist hún á fjögurra ára eftirfylgd.$^{19}$ Fullnægjandi gögn um notkun kannabis og geðrofseinkenni lágu pá fyrir frá 81\% hópsins. Meðalaldur við upphaf rannsóknartímabilsins var 18,3 ár. Í ljós kom að sá hópur sem notaði kannabis við upphaf rannsóknarinnar var 1,7 sinnum líklegri til pess að hafa fengið að minnsta kosti eitt einkenni geðrofs fjórum árum síðar. Leiðrétt var fyrir aldri, kyni, félagslegri stöðu, búsetu í borg, áföllum í æsku, einkennum geðrofs við upphaf rannsóknar, reykingum, neyslu alkóhóls og annarra vímuefna. Áhættan var háð tíðni kannabis- 
Tafla II. Tilfellaviðmiðarannsóknir sem greinarhöfundar vísa til um tengsl kannabis og geðrofs.

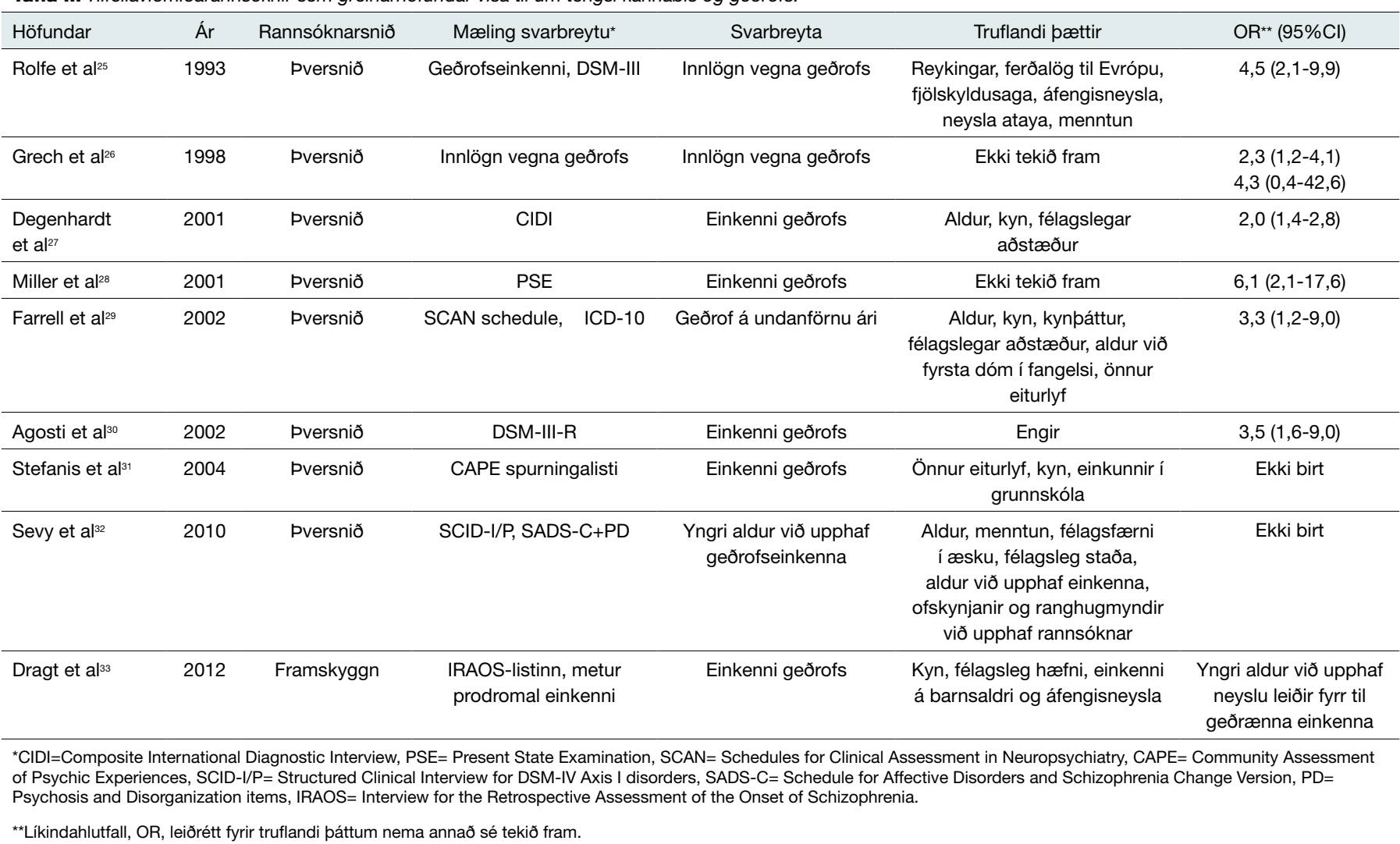

reykinga og pað reyndist vera marktækt línulegt samband á milli aukinnar notkunar og áhættu á geðrofi, OR 1,2 (95\%CI: 1,1-1,3) (tafla I).

Árið 2011 birtust niðurstöður tíu ára eftirfylgdar hópsins. ${ }^{20}$ Par kom fram að notkun kannabis jók áhættu á að fá einkenni geðrofs um 90\%; OR 1,9 (95\%CI 1,1-3,1) (tafla I). Jafnframt voru peir sem höfðu notað kannabis lengst líklegri en aðrir til að búa við prálát geðrofseinkenni; OR 2,2 (95\%CI 1,2-4,2).

\section{National Psychiatric Morbidity Survey}

Árið 2000 var gerð könnun í Bretlandi par sem fólk á aldrinum 16-74 ára var valið af handahófi og einkenni ýmissa geðsjúkdóma metin með stöðluðu viðtali. ${ }^{21}$ Alls taldi úrtakið 8500 manns og var peim sem uppfylltu nægilega mörg skilyrði geðrænna einkenna, auk $20 \%$ einstaklinga sem reyndust ekki hafa nein slík einkenni, fylgt eftir 18 mánuðum síðar. Markmið rannsóknarinnar var að kanna algengi ýmissa geðsjúkdóma í samfélaginu og pætti sem kynnu að hafa áhrif á algengi peirra. ${ }^{21}$ Wiles og samverkamenn birtu grein byggða á pessu úrtaki árið 2006 par sem peir greindu frá algengi geðrofseinkenna. ${ }^{22}$ Við mat á áhættupáttum geðrofseinkenna voru peir sem höfðu kannabisfíkn rúmlega prisvar sinnum líklegri til að upplifa geðrofseinkenni í einpátta aðhvarfsgreiningu. Við fjölpátta aðhvarfsgreiningu lækkaði líkindahlutfallið pegar leiðrétt var fyrir truflandi páttum og var pá ekki lengur marktækt (tafla I).

\section{Mater - University Study of Pregnancy-rannsóknin (MUSP)}

Mater - University Study of Pregnancy er framskyggn rannsókn á úrtaki einbura og allra mæðra sem páðu pjónustu mæðraverndar frá Mater háskólanum í Brisbane í Ástralíu á árunum 1981 til 1984. ${ }^{23}$ Hópnum var fylgt eftir með ítarlegum spurningalistum varðandi heilsufar og venjur við 5, 14 og 21 árs aldur barnanna.

Árið 2010 birtist rannsókn um tengsl kannabisnotkunar og geðrofseinkenna við 21 árs aldur. ${ }^{24}$ Peir sem höfðu notað kannabis í 6 ár eða lengur voru tvisvar sinnum líklegri til að fá geðrof við 21 árs aldur en hinir sem ekki höfðu notað efnið (tafla I). Að auki voru tilfellin pöruð við systkini sín og aldur við upphaf notkunar kannabisefna og niðurstöður spurningalista um geðrofseinkenni borin saman. Peir sem höfðu byrjað að nota kannabis fyrr voru líklegri til að upplifa fleiri geðrofseinkenni samanborið við systkini sín. Í peirri greiningu var marktæk fylgni milli pess hversu snemma notkunin hófst og sögu um próun geðrofseinkenna við 21 árs aldur. ${ }^{24}$

\section{Tilfellaviðmiðarannsóknir}

Pó svo að framskyggnar ferilrannsóknir séu pað rannsóknarsnið sem er best til pess fallið að varpa ljósi á tengsl kannabisnotkunar og geðrofs geta tilfellaviðmiðarannsóknir einnig lagt nokkuð af mörkum pegar kannað er samband skýribreytna og sjaldgæfra sjúkdóma. Í leit okkar komu upp 9 tilfellaviðmiðarannsóknir byggðar á jafnmörgum rannsóknarpýðum.

Sú fyrsta sem birtist var eftir Rolfe og samverkamenn og var gerð á hópi fólks í Gambíu ${ }^{25}$ og birtist árið 1993. Í peirri rannsókn var kannabis mælt í pvagi og spurningalistar lagðir fyrir fólk sem lagðist inn vegna geðrofs. Hópurinn var borinn saman við viðmiðahóp sem var valinn úr hópi vina og skyldfólks tilfellahópsins. Kannabisnotkun mældist par sem einn af áhættupáttum geðrofs, OR 4,5 (95\%CI 2,1-9,9) (tafla II). 
Grech og félagar birtu árið 1998 rannsókn par sem kannabisnotkun var metin sem áhættupáttur fyrir geðrofi í tveimur menningarheimum, ólíkum hvað varðar viðhorf til kannabisefna. ${ }^{26}$ Sjúklingar sem voru lagðir inn vegna geðrofs voru bornir saman við viðmiðunarhóp í hvoru landi fyrir sig með tilliti til neyslu áfengis og vímuefna. Kannabisnotkun var algengari hjá peim sem höfðu veikst af geðrofi í báðum löndum en notkun annarra vímuefna sambærileg. Reiknað líkindahlutfall peirra er notuðu kannabis áður en peir lögðust inn vegna geðrofs var 2,3 (95\%CI 1,2-4,1) í London og 4,3 (95\%CI 0,4-42,6) á Möltu. Ekki kom fram í grein peirra hvort um leiðrétt eða hrátt líkindahlutfall væri að ræða (tafla II).

Árið 2000 var gerð lýsandi faraldsfræðileg könnun á algengi geðsjúkdóma í Ástralíu, á áhrifum peirra og meðferð. Rannsökuð voru tengsl kannabisnotkunar og geðrofseinkenna í úrtaki 10.641 einstaklings. ${ }^{27}$ Eitt viðtal var tekið við pátttakendur og peir beðnir að svara spurningum um kannabisnotkun undanfarna 12 mánuði ásamt stöðluðum spurningalista um geðrofseinkenni á sama tímabili. Niðurstöður studdu að kannabisnotkun væri sjálfstæður áhættupáttur fyrir próun geðrofseinkenna (tafla II).

Miller og samverkamenn rannsökuðu áhrif ýmissa skýribreytna á geðrofseinkenni og próun geðrofssjúkdóma hjá há-áhættuhópi í Skotlandi. ${ }^{28}$ Hópurinn var skilgreindur pannig að pátttakendur ættu að minnsta kosti tvo fyrstu eða annarrar gráðu ættingja með geðklofa en væru ekki sjálfir með pekktan geðrofssjúkdóm. Alls samanstóð tilfellahópurinn af 155 einstaklingum á aldrinum 16 til 25 ára. Hann var borinn saman við viðmiðahóp sem var fenginn úr tengslaneti tilfellanna eða úr félagsmiðstöðvum Edinborgar. Niðurstöður rannsakenda voru að kannabisnotkun jók líkur á geðrofseinkennum og að auki var skammtaháð samband til staðar milli kannabisneyslu og geðrofs hjá báðum hópum. Ekki var munur á milli hópanna (tafla II).

Algengi vímuefnaneyslu og geðrofseinkenna meðal fanga er almennt meira en gengur og gerist í almennu pýði. Pví gerðu Farrell og samverkamenn rannsókn á föngum víðs vegar um England til pess að kanna tengsl kannabisnotkunar og geðrofseinkenna í peirra hópi. ${ }^{29}$ Alls tóku fangar í 131 fangelsi pátt í rannsókninni og voru 3563 fangar teknir í fyrsta viðtal. Einum af hverjum fimm föngum var boðið að fara í frekara mat og var rannsóknin byggð á gögnum frá 503 föngum. Niðurstöður fjölpátta aðhvarfsgreiningar sýndu að kannabisfíkn væri sjálfstæður áhættupáttur fyrir geðrofseinkennum hjá föngunum (tafla II).

Á árunum 1990 til 1992 var gerð rannsókn á úrtaki Bandaríkjamanna á aldrinum 15 til 54 ára til að kanna algengi geðsjúkdóma í samfélaginu. Úr peim gögnum var unnin rannsókn sem lýsti algengi geðsjúkdóma meðal fanga með kannabisfíkn. ${ }^{30}$ Agosti og samverkamenn birtu töflu yfir ýmsar geðgreiningar sem kannabisfíklar voru líklegri til hafa miðað við pá sem ekki voru háðir eða notuðu reglulega kannabis. Meðal peirra var geðrof (tafla II). Ekki voru birt leiðrétt líkindahlutföll í greininni.

Grísk rannsókn frá árinu 2004 sýndi línuleg tengsl kannabisnotkunar við ýmis einkenni geðrofs. ${ }^{31}$ Rannsóknin var pversniðsrannsókn og unnin sem hluti af framskyggnri ferilrannsókn á úrtaki fólks sem fæddist í apríl árið 1983. Við 18 ára aldur voru lagðir fyrir spurningalistar sem meðal annars mátu kannabisnotkun um ævina og einnig algengi próunar geðrofseinkenna og geðraskana. Helstu svarbreytur voru megineinkenni geðrofs: ofskynjanir, að-

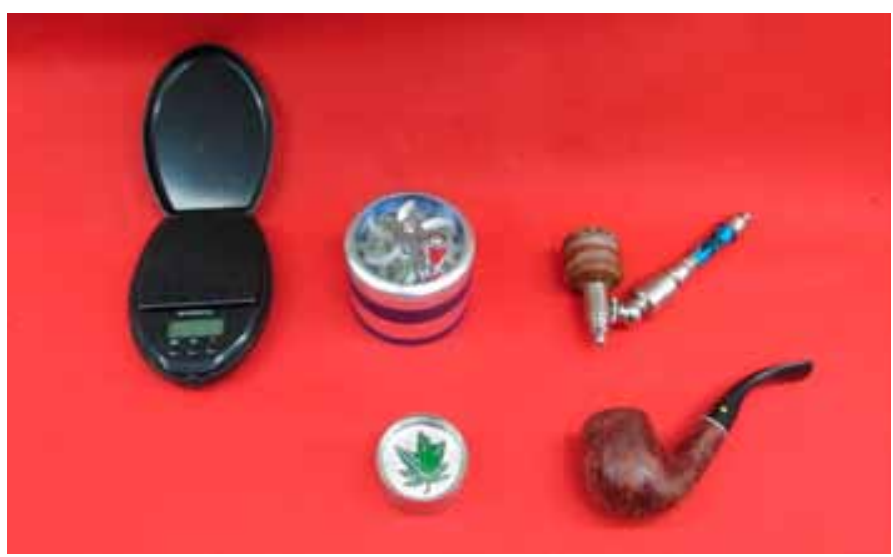

Mynd 2. Tól tengd hassneyslu: Vigt, kvarnir og pípur. Mynd birt með leyfi lögreglu höfuðborgarsvæðisins.

sóknarkennd, mikilmennska og fyrsta stigs einkenni Schneiders (first rank symptoms). Niðurstöður voru birtar á formi aðhvarfsstuðuls (regression coefficient) og sýndu marktæka fylgni milli pess að nota kannabis daglega og allra ofangreindra svarbreytna. Mest var fylgnin við ofskynjanir. Að auki benti rannsóknin til pess að sterkari tengsl væru við allar svarbreytur hjá peim hluta hópsins er hóf notkun fyrir 15 ára aldur.

Ein lítil rannsókn frá 2010 sýndi ekki marktæk tengsl milli aldurs við upphaf notkunar kannabisefna og aldurs við próun fyrstu einkenna geðrofs. ${ }^{32}$ Í rannsókninni voru 49 geðklofasjúklingar með fíkniheilkenni af völdum kannabisefna bornir saman við 51 geðklofasjúkling sem ekki hafði slíka sögu. Niðurstöður höfunda á grunni pessara fámennu hópa voru meðal annars pær að kannabisnotkun væri ekki sjálfstæður áhættupáttur fyrir snemmkomnum geðrofseinkennum. Styrkur slíkrar rannsóknar er pó nær enginn til að svara slíkum spurningum vegna lítils fjölda tilfella og viðmiða.

Í rannsókn sem birt var árið 2012 spurðu höfundar peirrar spurningar hvort kannabisnotkun á unglingsaldri hefði meiri áhrif á próun geðrofseinkenna en kannabisnotkun á fullorðinsaldri. ${ }^{33}$ Rannsóknin var hluti af stærri rannsókn, EPOS (European Prediction of Psychosis Study). Úrtak rannsóknarinnar voru einstaklingar sem voru taldir í aukinni áhættu á að fá geðrofseinkenni. Við upphaf rannsóknar voru spurningalistar lagðir fyrir með tilliti til einkenna geðrofs, kvíða og vímuefnaneyslu. Peim var fylgt eftir í 18 mánuði. Niðurstöður voru að marktæk fylgni reyndist á milli lægri aldurs við upphaf notkunar kannabisefna og kvíða, minnisleysis og skertrar einbeitingar á eftirfylgdartímanum. Drógu höfundar pá ályktun að fylgni væri á milli kannabisnotkunar á unglingsaldri og ýmissa geðrænna einkenna í EPOShópnum.

\section{Umræða}

Pegar niðurstöður ferilrannsókna eru teknar saman, styðja pær að notkun kannabis sé sjálfstæður áhættupáttur fyrir geðrof og próun geðklofa. Margt styður að um orsakasamband sé að ræða fremur en tilviljunarháða fylgni. Í fyrsta lagi ber niðurstöðum peirra flestra saman: kannabisnotkun virðist auka marktækt líkur á geðrofi og er áhættan sem fylgir reglulegri kannabisnotkun af 
svipaðri stærðagráđu í flestum rannsóknunum. Í öðru lagi er tímasambandinu milli skýribreytu (kannabis) og svarbreytu (geðrof) gerð góð skil í flestum ferilrannsóknanna. Oft hefur hugmyndin um sjálflyfjun (self-medication hypothesis) verið nefnd í pessu rannsóknarsamhengi. Samkvæmt henni eru peir sem veikjast af geðrofi líklegri til að nota kannabis eftir að einkennin koma fram, til að draga úr geðrænum einkennum veikinda sinna. ${ }^{34,35}$ Marktæk fylgni kannabisnotkunar og geðrofs pegar tekið hefur verið tillit til tímasamhengisins á milli notkunar efnanna og geðrofs í ferilrannsóknum styður ekki pessa kenningu. Í priðja lagi kemur fram skammtaháð samband í mörgum af rannsóknunum.,13,18,19 Раð styður að kannabis hafi áhrif á geðrof par sem áhætta reynist aukast í samhengi við aukna tíðni kannabisneyslu og er almennt mest í ferilrannsóknum hjá peim sem hafa verið í daglegri neyslu.

Í ferilrannsóknum kemur einnig fram að notkun kannabis á unglingsaldri hafi sterkari tengsl við geðrof og próun geðklofa en pegar notkun pess hefst fyrst hjá fullorðnum. ${ }^{19,20,24}$ Margt bendir til pess að kannabisnotkun á unglingsaldri hafi víðtæk áhrif á vitsmunaproska og geti meðal annars valdið lakara minni og einbeitingarskorti. ${ }^{36,37}$ Pví er líklegt að miðtaugakerfi unglinga sé viðkvæmara fyrir eitrunaráhrifum kannabis en miðtaugakerfi fullorðinna, sem skýri sterk tengsl kannabisnotkunar unglinga og próunar geðrofssjúkdóma í kjölfarið. Rannsóknir sem gerðar hafa verið á péttni kannabisviðtaka í miðtaugakerfinu benda til pess að hún sé mest á fósturstigi en minnki jafnt og pétt pangað til fullorðinsaldri er náo. ${ }^{38}$ Notkun kannabis á peim tíma, áđur en péttni viðtakanna nær lágmarki sínu, gæti pví fremur útsett unglinga fyrir ýmsum kvillum í miðtaugakerfinu, til dæmis geðrofssjúkdómum, en fullorðna notendur. Tilgátur eru uppi um að röskun á samspili cannabinoidviðtaka (CB1 og CB2) og dópamínviðtaka hafi áhrif á próun geðrofssjúkdóma. ${ }^{39}$ Rannsóknir hafa sýnt að tengingar taugasíma í heila einstaklinga sem hófu kannabisnotkun á unglingsaldri voru færri á vissum svæðum borið saman við viðmiðunarhóp. ${ }^{38}$ Félagsleg áhrif kannabisnotkunar kunna einnig að vera háð aldri og pað kann að skipta máli í pessu samhengi. Fólk sem hefur notkun pess á unglingsaldri kann að vera líklegra til að falla út úr skóla og einangrast félagslega fyrr en hinir sem hefja notkun á fullorðinsaldri. Рað kann vitaskuld að skipta máli hvað varðar próun geðrofssjúkdóma.

Pó svo að niðurstöður ferilrannsóknanna séu nokkuð samhljóma má pó benda á nokkrar takmarkanir sem erfitt er að yfirstíga að fullu. Í fyrsta lagi meta pátttakendur par kannabisnotkun nær alltaf eftir minni og pví er viss hætta á minnisbjögun. Hins vegar er afar ólíklegt að hún sé á pann veg að tengsl kannabisnotkunar og geðrofs verði ofmetin fyrir vikið. Miklu líklegra er raunar að notkun vímugjafa sé almennt frekar vanmetin en ofmetin af notendum í faraldsfræðirannsóknum líkt og almennt gildir um slíka svörun í klínískum aðstæðum. Í öðru lagi er meginsvarbreyta flestra rannsóknanna einkenni geðrofs sem parf ekki í öllum tilvikum að próast yfir í eiginlegan geðrofssjúkdóm eins og geðklofa. Í nýlegri rannsókn var rúmlega 18.000 einstaklingum fylgt eftir sem höfðu greinst með geðrof af völdum einhvers tiltekins vímuefnis og mælt hversu hátt hlutfall peirra veiktist síðar af geðklofa..$^{40}$ Einstaklingar sem höfðu fengið geðrof vegna kannabisnotkunar voru í mestri áhættu á að próa með sér geðklofa, eða
$46 \%$ notenda. ${ }^{40}$ Aðrar rannsóknir hafa gefið svipaðar niðurstöður og sýnt að einkenni kannabistengds geðrofs geta verið langvinn og leitt til langvinns geðrofssjúkdóms eins og geðklofa. ${ }^{41,42}$

Safngreining sem birtist árið 2007 tók saman pær ferilrannsóknir sem pá höfðu birst um tengsl kannabisnotkunar og geðrofs. ${ }^{43}$ Í ljós kom að safnlíkindahlutfall peirra sem höfðu einhvern tímann notað kannabis var tæplega helmingi hæra en hjá viðmiðunarhópnum: 1,4 (95\%CI: 1,2-1,7) og tvöfalt hærra hjá peim notendum sem voru í mestri neyslu en hjá viðmiðunarhópnum: 2,1 (95\%CI: 1,5-2,8). Höfundarnir komust að peirri niðurstöðu að enn væri ekki hægt að segja til um hvernig eða hvort kannabis valdi geðrofi en vísbendingarnar væru sterkar og pví mikilvægt að vara ungt fólk við peirri hættu á geðrofi sem kann að fylgja neyslu kannabisefna. Önnur safngreining árið 2011 komst að peirri niðurstöðu að aldur við fyrsta geðrof var 2,7 árum fyrr hjá peim sem notuðu kannabis samanborið við pá sem ekki höfðu notað pað. ${ }^{44}$

Flestar pær tilfellaviðmiðarannsóknir sem gerðar hafa verið sýna fram á marktæk tengsl kannabisnotkunar við geðrof og styðja að kannabisnotkun geti leitt til geðrofs. Áhættuhlutföllin eru einnig í samræmi við niðurstöður ferilrannsóknanna. Í peim tilfellaviðmiðarannsóknum er pó erfiðara að draga skýrar ályktanir um samhengið vegna pess að áreiðanlegar mælingar á skýribreytu (kannabis) og samhengi pess við tímasetningu geðrofseinkenna skortir enn frekar en í ferilrannsóknum. Pegar álykta á um orsakasamhengi milli skýribreytna og svarbreytna eru framskyggnar ferilrannsóknir heppilegra snið en tilfellaviðmiðaðar pversniðsrannsóknir.

Bent hefur verið á að ef orsakatengsl væru á milli kannabis og geðrofs ætti algengi geðrofs að sveiflast samhliða breytingum á kannabisnotkun á síðustu áratugum. ${ }^{45}$ Pað er hins vegar mikil einföldun par sem flókið samhengi virðist vera hér á milli. Geðrofssjúkdómar geta tekið langan tíma að próast og pað er vandasamt að mæla skýribreytu og svarbreytu af nákvæmni, og pó sérstaklega samhengið á milli peirra. Einnig flækir málið að geðklofi er sjaldgæfari en geðrofseinkenni en á hinn bóginn stöðugri og áreiðanlegri svarbreyta en geðrof. Í sumum greinum benda rannsakendur á að algengi langvinnra geðrofssjúkdóma á geðdeildum endurspegli ekki algengi skammvinns geðrofs eða geðrofseinkenna í samfélaginu og byrði kannabis í pví samhengi sé pví ef til vill meiri en oft er talið. ${ }^{41,46,47}$

Flestir sem nota kannabis reglulega virðast stundum upplifa væg en skammvinn geðrofseinkenni sem eru skammtaháð og tengd styrk THC. Rannsóknir sem gerðar hafa verið á undanförnum árum benda til pess að styrkur THC fari víða vaxandi í peim kannabisefnum sem eru á markaði. ${ }^{48,49}$ Petta er áhyggjuefni par sem THC er pað efni í kannabisafleiðum sem eykur mest hættu á geðrofi og pessi próun gæti pví orðið til pess að auka líkur á geðrofseinkennum hjá notendum. Í ljósi peirra gagna sem við höfum kynnt í pessari yfirlitsgrein teljum við afar mikilvægt að auka pekkingu lækna, annarra heilbrigðisstétta og almennings á alvarlegum afleiðingum reglulegrar kannabisnotkunar hjá unglingum og ungum fullorðnum, ${ }^{50}$ og ekki síður á peirri staðreynd að раð er ekki hægt að spá fyrir um hverjir í hópi notenda kannabisefna veikist illa og til lengri tíma. 


\section{Heimildir}

1. Organization WH. Management of substance abuse 2013 who.int/substance_abuse/facts/cannabis/en/ - apríl 2014.

2. Vímuefnaneysla unglinga í efstu bekkjum grunnskóla á Íslandi: Próun frá 1997 til 2012: Rannsóknir og greining, Háskólinn í Reykjavík 2012.

3. Ashton $\mathrm{CH}$. Pharmacology and effects of cannabis: a brief review. Br J Psychiatry 2001; 178: 101-6.

4. Andreasson S, Allebeck P, Engstrom A, Rydberg U. Cannabis and schizophrenia. A longitudinal study of Swedish conscripts. Lancet 1987; 2: 1483-6.

5. Degenhardt L, Hall W. The association between psychosis and problematical drug use among Australian adults: findings from the National Survey of Mental Health and Well-Being. Psychol Med 2001; 31: 659-68.

6. Kessler RC, Crum RM, Warner LA, Nelson CB, Schulenberg J, Anthony JC. Lifetime co-occurrence of DSM-III-R alcohol abuse and dependence with other psychiatric disorders in the National Comorbidity Survey. Arch Gen Psychiatry 1997; 54: 313-21.

7. Regier DA, Farmer ME, Rae DS, Locke BZ, Keith SJ, Judd LL, et al. Comorbidity of mental disorders with alcoho and other drug abuse. Results from the Epidemiologic Catchment Area (ECA) Study. JAMA 1990; 264: 2511-8.

8. Andreasson S, Allebeck P, Rydberg U. Schizophrenia in users and nonusers of cannabis. A longitudinal study in Stockholm County. Acta Psychiatr Scand 1989; 79: 505-10.

9. Zammit S, Allebeck P, Andreasson S, Lundberg I, Lewis G. Self reported cannabis use as a risk factor for schizophrenia in Swedish conscripts of 1969: historical cohort study. BMJ 2002; 325: 1199 .

10. Manrique-Garcia E, Zammit S, Dalman C, Hemmingsson T, Andreasson S, Allebeck P. Cannabis, schizophrenia and other non-affective psychoses: 35 years of follow-up of a population-based cohort. Psychol Med 2012; 42: 1321-8.

11. Eaton WW, Regier DA, Locke BZ, Taube CA. The Epidemiologic Catchment Area Program of the National Institute of Mental Health. Public Health Rep 1981; 96 319-25.

12. Tien AY, Anthony JC. Epidemiological analysis of alcohol and drug use as risk factors for psychotic experiences. J Nerv Ment Dis 1990; 178: 473-80.

13. van Os J, Bak M, Hanssen M, Bijl RV, de Graaf R, Verdoux $\mathrm{H}$. Cannabis use and psychosis: a longitudinal populationbased study. Am J Epidemiol 2002; 156: 319-27.

14. Arseneault L, Cannon M, Poulton R, Murray R, Caspi A, Moffitt TE. Cannabis use in adolescence and risk for adult psychosis: longitudinal prospective study. BMJ 2002; 325: 1212-3.

15. Yung AR, McGorry PD, Francey SM, Nelson B, Baker K, Phillips LJ, et al. PACE: a specialised service for young people at risk of psychotic disorders. Med J Aust 2007; 187: S43-6.

16. Phillips LJ, Curry C, Yung AR, Yuen HP, Adlard S, McGorry PD. Cannabis use is not associated with the development of psychosis in an ,ultra' high-risk group. Aust N Z J Psychiatry 2002; 36: 800-6.

17. Fergusson DM, Horwood LJ, Swain-Campbell NR Cannabis dependence and psychotic symptoms in young people. Psychol Med 2003; 33: 15-21.

18. Fergusson DM, Horwood LJ, Ridder EM. Tests of causa linkages between cannabis use and psychotic symptoms. Addiction 2005; 100: 354-66.
19. Henquet C, Krabbendam L, Spauwen J, Kaplan C, Lieb R, Wittchen $\mathrm{HU}$, et al. Prospective cohort study of cannabis use, predisposition for psychosis, and psychotic symptoms in young people. BMJ 2005; 330: 11

20. Kuepper R, van Os J, Lieb R, Wittchen HU, Hofler M, Henquet $\mathrm{C}$. Continued cannabis use and risk of incidence and persistence of psychotic symptoms: 10 year follow-up cohort study. BMJ 2011; 342: d738.

21. Singleton N, Bumpstead R, O’Brien M, Lee A, Meltzer H. Psychiatric morbidity among adults living in private households, 2000 (Reprinted from Psychiatric morbidity among adults living in private households, 2000: Summary report,, 2001). Int Rev Psychiatry 2003; 15: 65-73.

22. Wiles NJ, Zammit S, Bebbington P, Singleton N, Meltzer $\mathrm{H}$, Lewis G. Self-reported psychotic symptoms in the general population: results from the longitudinal study of the British National Psychiatric Morbidity Survey. Br J Psychiatry 2006; 188: 519-26.

23. Najman JM, Bor W, O'Callaghan M, Williams GM, Aird R, Shuttlewood G. Cohort Profile: The Mater-University of Queensland Study of Pregnancy (MUSP). Int J Epidemiol 2005; 34: 992-7.

24. McGrath J, Welham J, Scott J, Varghese D, Degenhardt L, Hayatbakhsh MR, et al. Association between cannabis use and psychosis-related outcomes using sibling pair analysis in a cohort of young adults. Arch Gen Psychiatry 2010; 67: 440-7.

25. Rolfe M, Tang CM, Sabally S, Todd JE, Sam EB, Hatib N'Jie AB. Psychosis and cannabis abuse in The Gambia. A casecontrol study. Br J Psychiatry 1993; 163: 798-801.

26. Grech A, Takei N, Murray RM. Comparison of cannabis use in psychotic patients and controls in London and Malta. Schizophr Res 1998; 29: 22

27. Degenhardt L, Hall W. The association between psychosis and problematical drug use among Australian adults: findings from the National Survey of Mental Health and Well-Being. Psychol Med 2001; 31: 659-68.

28. Miller P, Lawrie SM, Hodges A, Clafferty R, Cosway R, Johnstone EC. Genetic liability, illicit drug use, life stress and psychotic symptoms: preliminary findings from the Edinburgh study of people at high risk for schizophrenia. Soc Psychiatry Psychiatr Epidemiol 2001; 36: 338-42.

29. Farrell M, Boys A, Bebbington P, Brugha T, Coid J, Jenkins $\mathrm{R}$, et al. Psychosis and drug dependence: results from a national survey of prisoners. Br J Psychiatry 2002; 181 393-8.

30. Agosti V, Nunes E, Levin F. Rates of psychiatric comorbidity among U.S. residents with lifetime cannabis dependence. Am J Drug Alcohol Abuse 2002; 28: 643-52.

31. Stefanis NC, Delespaul P, Henquet C, Bakoula C, Stefanis $\mathrm{CN}$, Van Os J. Early adolescent cannabis exposure and positive and negative dimensions of psychosis. Addiction 2004; 99: 1333-41.

32. Sevy S, Robinson DG, Napolitano B, Patel RC, GunduzBruce $H$, Miller R, et al. Are cannabis use disorders associated with an earlier age at onset of psychosis? A study in first episode schizophrenia. Schizophr Res 2010; 120: 101-7.

33. Dragt $\mathrm{S}$, Nieman $\mathrm{DH}$, Schultze-Lutter $\mathrm{F}$, van der Meer $\mathrm{F}$ Becker $\mathrm{H}$, de Haan L, et al. Cannabis use and age at onset of symptoms in subjects at clinical high risk for psychosis. Acta Psychiatr Scand 2012; 125: 45-53.
34. Dixon L, Haas G, Weiden P, Sweeney J, Frances A. Acute effects of drug abuse in schizophrenic patients: clinical observations and patients' self-reports. Schizophr Bull 1990; 16: 69-79.

35. Peralta V, Cuesta MJ. Influence of cannabis abuse on schizophrenic psychopathology. Acta Psychiatr Scand 1992; 85: 127-30.

36. Meier MH, Caspi A, Ambler A, Harrington H, Houts R Keefe RSE, et al. Persistent cannabis users show neuropsychological decline from childhood to midlife. Proc Natl Acad Sci U S A 2012; 109: E2657-E64.

37. Solowij N, Stephens RS, Roffman RA, Babor T, Kadden R, Miller $\mathrm{M}$, et al. Cognitive functioning of long-term heavy cannabis users seeking treatment. JAMA 2002; 287: 112331.

38. Glass M, Dragunow M, Faull RLM. Cannabinoid receptors in the human brain: A detailed anatomical and quantitative autoradiographic study in the fetal, neonatal and adult human brain. Neuroscience 1997; 77: 299-318.

39. Laviolette SR, Grace AA. The roles of cannabinoid and dopamine receptor systems in neural emotional learning circuits: implications for schizophrenia and addiction. Cell Mol Life Sci 2006; 63: 1597-613.

40. Kirkbride J. The risk of substance-induced psychosis converting to schizophrenia varies with substance used and patient age. Evid Based Ment Health 2013; 16: 65.

41. Johns LC, van Os J. The continuity of psychotic experiences in the general population. Clin Psychol Rev 2001; 21: $1125-41$.

42. van Os J, Linscott RJ, Myin-Germeys I, Delespaul P, Krabbendam L. A systematic review and meta-analysis of the psychosis continuum: evidence for a psychosis proneness-persistence-impairment model of psychotic disorder. Psychol Med 2009; 39: 179-95.

43. Moore TH, Zammit S, Lingford-Hughes A, Barnes TR, Jones PB, Burke M, et al. Cannabis use and risk of psychotic or affective mental health outcomes: a systematic review. Lancet 2007; 370: 319-28.

44. Large M, Sharma S, Compton MT, Slade T, Nielssen O. Cannabis Use and Earlier Onset of Psychosis. Arch Gen Psychiatry 2011; 68: 555-61.

45. Degenhardt L, Hall W, Lynskey M. Testing hypotheses about the relationship between cannabis use and psychosis. Drug Alcohol Depend 2003; 71: 37-48.

46. van Os J, Hanssen M, Bijl RV, Vollebergh W. Prevalence of psychotic disorder and community level of psychotic symptoms: an urban-rural comparison. Arch Gen Psychiatry 2001; 58: 663-8.

47. Verdoux H, Maurice-Tison S, Gay B, Van Os J, Salamon R, Bourgeois ML. A survey of delusional ideation in primarycare patients. Psychol Med 1998; 28: 127-34.

48. Pijlman FT, Rigter SM, Hoek J, Goldschmidt HM, Niesink RJ. Strong increase in total delta-THC in cannabis preparations sold in Dutch coffee shops. Addict Biol 2005; 10: $171-80$

49. Vindenes V, Strand DH, Kristoffersen L, Boix F, Morland J. Has the intake of THC by cannabis users changed over the last decade? Evidence of increased exposure by analysis of blood THC concentrations in impaired drivers. Forensic Sci Int 2013; 226: 197-201

50. Volkov ND, Baler RD, Compton WN, Weiss SRB. Adverse health effects of marijuana use. N Engl J Med 2014; 370: 2219-27. 
ENGLISH SUMMARY

\section{Does the use of cannabis increase the risk for psychosis and the development of schizophrenia?}

Arnar Jan Jonsson ${ }^{1}$, Hera Birgisdottir ${ }^{1}$, Engilbert Sigurdsson ${ }^{1,2}$

Over the past 30 years evidence has been growing that cannabis use increases the risk for psychosis which could develop into schizophrenia in a proportion of cases. Over the past decade many studies have been published which clarify the association between cannabis use and psychosis. The aim of this review is to examine this association. A systematic search yielded 14 cohort studies carried out in 9 cohorts and 9 casecontrol studies. When the results of these studies are taken together they unambiguously support that cannabis use is an independent risk factor for psychosis and may also give rise to chronic psychotic disorders like schizophrenia. A dose dependent link is present because more frequent use associates with greater risk. The studies also show that cannabis-use in adolescence is associated with greater risk of developing psychosis than commencing the use of cannabis in adulthood. Further studies are needed to explain this association since psychotic disorders take years to evolve and it remains difficult to measure both the explanatory and the response variable and their complex relationship. The results emphasize the need to enhance public knowledge on the possible consequences of cannabis use and the fact that it cannot be predicted who will experience transient psychosis and who will develop a chronic psychotic disorder.

Key words: Cannabis, psychosis, schizophrenia, association.

Correspondence: Engilbert Sigurdsson, engilbs@landspitali.is

${ }^{1}$ Faculty of Medicine, University of Iceland, ${ }^{2}$ Mental Health Services, Landspitali-University Hospital. 